\title{
The Mediating Role of Trust in Management on Job Satisfaction and Organizational Commitment
}

\author{
Binod Ghimire, Ph.D. \\ Lecturer, Nepal Commerce Campus, T.U.
}

\begin{abstract}
Purpose- The paper aims to empirically testing the mediating effect of trust in management in the relationship between organizational justice and personal outcomes. The main purpose of this study is to understand mediating role of trust in the management on organizational justice and its impact on job satisfaction and organizational commitment.
\end{abstract}

Approach-The study is based on the effect of organizational justice, trust in management, job satisfaction and organizational commitment among nursing staff working at different hospitals at Kathmandu Valley. This study incorporates design and distribution of questionnaire to 160 nurses belonging to different hospitals working on different scale of pay level.

Findings- Organizational justice alone does not significantly increase job satisfaction as well as commitment in the organization. Trust in management mediates the relationship organizational justice and personal outcome. Organizational justice positively affect personal outcome when mediated by high trust in management.

Practical implication- This paper is useful to academicians and organizations to understand the impact of trust in management on the work performance. This study provides practical implications towards nurses and management of hospitals. Management requires change in behavior to develop trusting environment in workplace.

Keywords- Organizational Justice, Trust in management, Nurses, Organizational Commitment, Job Satisfaction

\section{Introduction}

Nursing is generally perceived as a stressful career choice. However, this is attractive career among teenagers. This is the reflection of the development in the health care system and nursing profession. It is both physically and psychologically challenging as it is directly associated with the wellbeing of patient. Small carelessness may result severe condition of patient. The cost of commitment in this job is very high while compared to other profession. Thus, management must pay attention to create environment of justice, trust and equity in organizational behavior. The widespread nursing shortage and nurses' high turnover has become global issue (Kingma, 2001). The nursing workforce in Nepal also faces the same trend due to the challenges in retaining of them. Retention of nurse is persistent problem associated with job satisfaction 
and commitment. There is urgent need for rigorous research regarding trust, equity, job satisfaction and commitment to ensure right nurse employment strategies in Nepal.

\section{Statement of Problem}

Numerous research studies have been conducted to determine the antecedents of trust focusing on personal factors (Mayer et al., 1995; McAllister, 1995). Ability, benevolence, and integrity of trustee have been identified as representative indicators of personal level antecedents of trust (Dietz \& Hartog, 2006; Mayer et al., 1995). OJ is relatively more impactful among white-collar employees (Herr, Bosch, et al., 2014; Herr et al., in press), which has been attributed to their specific relationship with their employer, involving obligations and expectations beyond the formal contract, implying high levels of commitment and trust (Herr, Bosch, et al., 2014).

This study investigated the antecedents and consequences of trust in top management. Subsequent relationships between organizational justice and trust in management and organizational commitment were also of concern to this research because relatively little research has been conducted on that area despite its significance. On the basis of above discussion, there is guiding research questions for this purpose; Is trust in top management a mediator between organizational justice, job satisfaction and organizational commitment?

\section{Conceptual Framework and Research Hypothesis}

Based on the research question, following conceptual framework and hypothesis have been developed. The overall study of this research paper can be described in the conceptual framework in this way;

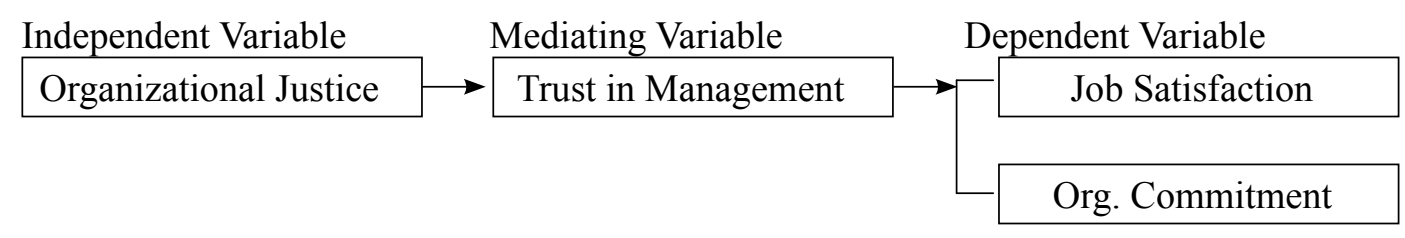

Figure1: Distributive Justice Mediates the Relationship between Organizational Justice and Personal Outcomes

H1: Trust in Management mediates the effect of Organizational Justice on Job Satisfaction.

H2: Trust in Management mediates the effect of Organizational Justice on Organizational Commitment.

\section{Literature Review}

The nursing service paradigm shifts from vocational services (services based on skills only) toward professional services (services with mastering the science and technology and nursing specialties). This has created hospital work more dynamics, and leading individual work to teamwork. This condition is promoting a high collectivism value or togetherness and making people more concern to group interest rather than individual interest. The concept of organizational justice has been driven from different angles by different researchers. Common understanding of organizational justice is overall perceptions of fairness in all organizational processes and practices and they influence the behavior and work outcomes. Social exchange theory based on justice states that individuals expect that they will get the business exchange and fair remuneration from organization (Tyler, 1994). Judgment relating to result allocation referred to distributive justice (Greenberg, 1990). The second issue is the assessment of organizational justice which is concerned with process elements, and known as procedural justice. Procedural justice refers to the process in which decision is taken (Konovsky, 2000). Furthermore, the third issue is the assessment of justice toward the interpersonal relationships referred as interactional justice where the study goes beyond decision outcomes and formal decision making procedures. It is all about how the people react to their perceptions 
regarding the social sensitivity of the interpersonal treatment they receive from decision makers. (Bies and Moag,1986). Trust in managers is important issue in subordinate and management relation. It is the way to lead and motivate subordinate in realizing a leader's vision. It requires consistent leadership in statements and actions. Trust is the most important part of a bond. According to Blau (1964) there are two ways for building trust, namely: (a) perform duties on a regular basis (reply to the benefits received from the other party), and (b) the development of exchanges in accordance with the passage of time. The trust in a social or organizational context has a systemic effect on structure, process, and operational efficiency. Trust building is the value of organization. It is expressed to relate goal setting, risk taking, exchange of information, decision-making, performance management, and collaboration. Trust is the result of a process of very favorable social exchange. There is higher OCB when there is high level of trust held in between subordinate and superiors within organization (Blau, 1964; Holmes, 1981). Various measures are helpful to create trust between the employer and employee, employee trust, supervisor with organization.

Job satisfaction is viewed as an employee's general attitude toward his or her job. It is positive reaction and action tendencies toward work (Vecchio, 1991; Vecchio, Hearn and Southey, 1992).Job satisfaction is defined as all the feelings that an individual has about his/her job (Spector, 1997) In a research on "Human Resource Management and Organizational Performance-An Evidence from Nepalese Banking Industry", it was indicated that performance evaluation and reward system variable is significantly positive correlation with return on equity (ROE) (Shrestha, 2006). The study reported that ROE is significantly and positively correlated with affective and continuous commitment. Here, employee satisfaction was closely related with all the HR practices components. Specifically, work related satisfaction was highly correlated with the work environment and climate.

\section{Justice Perception and Organizational Commitment}

Positive perceptions of distributive justice and procedural justice is directly associated with higher level of organizational commitment. Although, procedural justice is a better predictor of organizational commitment, some earlier research revealed that distributive justice also has a significant effect on organizational commitment (McFarlin and Sweeney, 1992)

Research indicates that fairness perceptions among employees influence a variety of important organizational outcomes (Cohen Charash and Spector, 2001; Colquitt, Conlon, Wesson, Porter and Ng, 2001). Rhodes and Streers (1981) found that pay equity was the most important contributor to the prediction of organizational commitment for a group of cooperative employees, while it was not a significant predictor of commitment for a group of conventional nature of employees. Lind and Tyler (1988) confirmed that procedural justice is more or highly influencing to institutional evaluations requiring a longterm perspective, like organizational commitment.

\section{Justice Perception and Trust in Management}

Employees will have a high level of trust in organization, if they are guaranteed fair procedural treatment (Sweeney-McFarlin, 1993:37). Similarly, Alexander and Ruderman's study also found that procedural justice showed substantial and unique effects on trust in management. After all, management researchers found that trust in management was an outcome of distributive justice and trust in management was affected significantly by procedural justice (Alexander-Ruderman, 1987). Procedural justice affected and employee's organizational commitment. Procedural justice has been found to have effect on the appraisal of the organization and its authorities, so it may exert some effects on trust in and commitment to the organization (Folger- Konowsky, 1989)

In the context of Nepal, there is dearth of research findings showing relations between specific HR procedure and commitment. Study with in Nepal conducted by Pandey (2008) indicates that employees in Nepalese banks still perceive a significant positive relationship among different nature of benefits such 
as, personal benefits, career benefits and job-related benefits of training and components of commitment i.e. affective commitment, continuous commitment and normative commitment). Regarding compliance, Adhikari and Gautam (2010) argue that government and employers have failed to follow and implement proper mechanism for implementing labour legislations at the organizational level. They have presented sufficient evidences about negligence from the part of these two parties to comply provisions of Labour legislations. Employers have been indulging workers that instead of being involved and committed employees are engaged in petty politics at work places. In one study by Ghimire, (2012) understanding fairness at work place would help managers and business organization in Nepal to formulate strategies. Strategies involve work factors such as distributive and procedural justice which helps to improve the management of human resource development. These strategies would help in influencing positive behaviors among employees, and hence achieve effectiveness and high productivity in the organization.

\section{The Mediating Role of Trust}

There are empirical evidences linking trust in organization to organizational commitment, intention to remain and the "civic virtue dimension" of citizenship behavior. (Robinson, 1996). As Blau (1964:94) noted, "By discharging their obligation for service rendered...individuals demonstrate their trustworthiness and the gradual expansion of mutual services." The findings of different studies presented by Konovsky and Pugh (1994) indicated that there are relationship between distributive justices and trust in managers. Relationship was found insignificant, while procedural justice affected significantly on the trust in managers. In addition, Rezaiean et al. (2010) found that there is insignificant effect of interactional justice toward trust in managers. However, relationship between procedural justices with OCB through trust in managers is positive and significant. High levels of trust are positively and causally linked with organizational commitment. It seems to be logical to expect that employees' trust in organization will affect their affective commitment and work behavior.

\section{Research Methodology}

Descriptive and correlation design has been employed in this study. Primary data is used to collect information about the perception of organizational justice, trust in management, job satisfaction and commitment. Questionnaires have been distributed to 160 respondents. They are selected by using convenient sampling. The questionnaires have been distributed to the nurses working at different hospital in Kathmandu valley. Structured questionnaire has been used as the tool for examining the level of perception regarding justice, trust, satisfaction and commitment prevailing in the different hospital under the study.

\section{Samples and Data Collection Process}

This study is based on a sample of 160 nurses working in Kathmandu Valley Hospitals. The sample was selected by using convenience sampling where the data collection was done from the nurses who were conveniently available to provide it. Nursing employees of a hospital in the Kathmandu valley were surveyed. Of the 200 surveys distributed, 160 were returned (response rate $=80 \%$ ). The job level of respondents also varied from officer to non-officer level. Demographic variables such as age, qualification, marital status, job position, types of hospital, total work experience, continuity in the current organization were included in the analysis to measure their influences on job satisfaction and commitment. After having a written permission from the firm's administration, questionnaire was distributed to 200 employees. Each questionnaire was accompanied by a letter explaining the purpose of the research, the voluntary nature of participation, and the confidentiality of the data. And a total of 160 completed questionnaires were returned ( 80 percent response rate) from 200 employees. All analyses described below are based on the data from these 160 subjects. 


\section{Measures and Statistical Tools}

Surveys were accompanied by a cover letter assuring confidentiality. The first section asked respondents about their demographic-related information including age, gender, marital status, educational level, job position, tenure and experience. Second sections contained questions tapping perceptions about the respondents' employing hospital and jobs/roles regarding organizational justice, trust in management, job satisfaction and organizational commitment. It is measured on a five-point Likert scale. Responses to all items were made on a 5-point Likert scale ranging from (1) "Strongly Disagree" to (5) "Strongly Agree". A five-point-rating scale was used to measure responses $(1=$ strongly disagree to $5=$ strongly agree $)$.

For the statistical instrument, the variable of organizational justice was measured using six items scale developed Niehoff and Moorman (1993). Trust in management was measured using four items scale developed by Mayer and Davis (1999). Job satisfaction was measured using five items scale developed by Warr, Cook, and Wall (1979). Similarly, commitment variable to the organization was measured through three items scale developed by Mowday, Steers, and Porter (1979). The measures were used to measure employee's commitment to his/her organization and it actually captures the attitudinal aspect of loyalty to the firm and psychological bonds to the organization. Mean, Standard deviation, Analysis of variance were used as statistical tools. Further, regression analysis is used to show the relationship among the variables under this study. In statistical analyses, SPSS version 13.0 was used. Cronbach's alpha test was used for the internal consistency, Spearman correlation coefficient to calculate the correlation between the variables was used in the study. And regression analysis was used because it provided estimates of net effects and explanatory power. The adjusted explained variance (the adjusted $\mathrm{R}$ square) was used in this research to measure explanatory power.

\section{Results}

\section{Sample Profile}

Table 1 presents the personal profiles of respondents. In terms of the gender structure, all were female. Majority of people are less than 25 years (35 percent). A large number of respondents had Bachelor degree in qualification (47 percent). Most of the respondents were married (58 percent). The majority of respondents were non officer or supporting staff (62 percent). Most of the nurses were involved in Private Hospital (42 percent). Majority of Respondents had worked for less than 5 years (47 percent) constitute nearly about one half of the sample. The biggest group of respondents constitutes less than 5 years (70 percent).

Table 1

Sample Profile

\begin{tabular}{|c|c|c|c|}
\hline Gender & Qualification & Job Position & Length of Service \\
\hline Female $=162$ & $\begin{array}{l}+2 \text { Nursing }=75 \\
\text { B.Sc. } / \mathrm{B} . \mathrm{N}=77 \\
\text { Master }=6 \\
\text { Others }=4\end{array}$ & $\begin{array}{l}\text { Non officer }=101 \\
\text { Officer }=61\end{array}$ & $\begin{array}{l}\text { Less than } 5 \text { years }=77 \\
6 \text { to } 10 \text { years }=62 \\
11 \text { to } 15 \text { years }=16 \\
\text { More than } 15 \text { years }=7\end{array}$ \\
\hline Age & Marital Status & Types of Hospital & $\begin{array}{l}\text { Continuity in the current } \\
\text { organization }\end{array}$ \\
\hline Less than 25 years $=57$ & Single $=67$ & Government $=45$ & Less than 5 years $=114$ \\
\hline 26 to 30 years $=51$ & Married $=95$ & Community $=37$ & 6 to 10 years $=41$ \\
\hline 31 to 35 years $=35$ & & Private $=68$ & More than 10 years $=7$ \\
\hline More than 35 years $=19$ & & Others $=12$ & \\
\hline
\end{tabular}




\section{Validity and Reliability Analyses for Measurement Scales}

Table 2 shows that results of validity and reliability analyses for measurement scales. The factor analysis with direct oblimin rotation was first analyzed for four variables with 18 items. After that, KaiserMayer- Olkin Test (KMO) was done to measure of sampling adequacy. It was conducted for each variable and the results were found acceptable. Relying on Hair, Anderson, Tatham, and Black's (1998) guideline, these statistical analyses showed that the value of factor analysis for all items that represent each research variable was 0.4 and more. This indicated that the items met the acceptable standard of validity analysis.

There is the acceptable standard of Kaiser-Meyer-Olkin's value i.e. 0.6. All variables were significant in Bartlett's test of sphericity. All research variables had eigenvalues larger than 1.The items for each research variable exceeded factor loadings of 0.40 . Besides that, all research variables exceeded the acceptable standard of reliability analysis of 0.70 (Nunally and Bernstein, 1994). These statistical results confirmed that the measurement scales used in this study met the acceptable standard of validity and reliability analyses.

Table 2

The Result of Validity and Reliability Analysis of Measurement Scales

\begin{tabular}{lccccccc}
\hline \multicolumn{1}{c}{ Measure } & Items & $\begin{array}{c}\text { Factor } \\
\text { Loadings }\end{array}$ & KMO & $\begin{array}{c}\text { Bartlett's Test of } \\
\text { Sphericity }\end{array}$ & $\begin{array}{c}\text { Eigen } \\
\text { Value }\end{array}$ & $\begin{array}{c}\text { Variance } \\
\text { Explained }\end{array}$ & $\begin{array}{c}\text { Cronbach } \\
\text { alpha }\end{array}$ \\
\hline Organizational & 6 & .447 to .847 & 0.878 & $517.324, \mathrm{P}=0.000$ & 3.874 & 64.560 & 0.884 \\
Justice & 4 & .755 to .804 & 0.762 & $259.670, \mathrm{P}=0.000$ & 2.662 & 66.562 & 0.829 \\
$\begin{array}{l}\text { Trust in Manager } \\
\text { Job Satisfaction }\end{array}$ & 5 & .697 to .877 & 0.782 & $339.653, \mathrm{P}=0.000$ & 3.087 & 61.742 & 0.841 \\
$\begin{array}{l}\text { Organizational } \\
\text { Commitment }\end{array}$ & 3 & .782 to .884 & 0.686 & $154.250, \mathrm{P}=0.000$ & 2.138 & 71.283 & 0.795 \\
\hline
\end{tabular}

Table 3 shows the results of Pearson correlation analysis and descriptive statistics. Means for all variables are between 3.065 and 3.152, signifying the levels of organizational justice, trust in management, job satisfaction and organizational commitment. The correlation coefficients for the relationship between the independent variable (i.e., organizational justice) and the mediating variables (i.e. trust in management) and the relationship between the independent variable (i.e organizational justice) and dependent variable (i.e., job satisfaction and organizational commitment) were less than 0.90 , indicating the data were not affected by any serious colinearity problem (Hair et al., 1998).

Table 3

Pearson Correlation Analysis and Descriptive Statistics

\begin{tabular}{lllllll}
\hline Variable & Mean & Standard Deviation & \multicolumn{5}{l}{ Pearson Correlation Analysis } \\
\hline & & & 1 & 2 & 3 & 4 \\
Organizational Justice & 3.099 & .7181 & 1 & & & \\
Trust in Management & 3.152 & .687 & $.810^{* *}$ & 1 & & \\
Job Satisfaction & 3.065 & .690 & $.870^{* *}$ & $.841^{* *}$ & 1 & \\
Organizational Commitment & 3.082 & .778 & $.847^{* *}$ & $.840^{* *}$ & $.845^{* *}$ & 1 \\
\hline
\end{tabular}

\section{Outcomes of Testing Research Hypotheses}

The mediating role of trust in management can be tested through regression analysis. Stepwise regression analysis was undertaken to test the effect of mediating variables. This method can assess the magnitude and direction of each independent variable, and vary the mediating variable relationship between 
many independent variables and one dependent variable (Foster, Stine and Waterman, 1998). According to Baron and Kenny (1986), the mediator variable can be clearly judged in terms of its magnitude. It can be confirmed through work practices such as when a previously significant effect of predictor variables is reduced to non-significant or reduced in terms of effect size after the inclusion of mediator variables into the analysis. The results of testing research hypotheses are shown in Table 4.

Table 4

Result for Stepwise Regression Analyses with Trust in Management as the Mediating Variable, Organizational as the Independent Variable and Personal Outcomes as the Dependent Variable

\begin{tabular}{|c|c|c|c|c|c|c|}
\hline \multirow[t]{2}{*}{ Variable } & \multirow[b]{2}{*}{ Step 1} & \multicolumn{2}{|c|}{ Job satisfaction } & \multicolumn{3}{|c|}{ Organizational Commitment } \\
\hline & & Step 2 & Step 3 & Step 1 & Step 2 & Step 3 \\
\hline $\begin{array}{l}\text { Control Variable } \\
\text { Age }\end{array}$ & .004 & -.044 & .005 & -.025 & -.071 & -.018 \\
\hline Qualification & -.059 & -.032 & -.026 & .022 & .048 & .055 \\
\hline Marital Status & -.034 & .008 & -.038 & .063 & .103 & .052 \\
\hline Job Position & .071 & .068 & .043 & -.001 & -.004 & -.031 \\
\hline Types of Hospital & .093 & .043 & .033 & .114 & .065 & .054 \\
\hline Total Work Experience & .015 & .026 & .060 & -.040 & -.029 & .008 \\
\hline $\begin{array}{l}\text { Continuity in the current } \\
\text { organization }\end{array}$ & .084 & .036 & .014 & .149 & .102 & .078 \\
\hline Independent Variable & & & & & & \\
\hline $\begin{array}{l}\text { Organizational Justice } \\
\text { Mediating Variable }\end{array}$ & & $.870 * * *$ & $.538 * * *$ & & $.848 * * *$ & $.482 * * *$ \\
\hline Trust in Management & & & $.407 * * *$ & & & $.450 * * *$ \\
\hline $\mathrm{R}^{2}$ & .010 & .763 & .818 & .016 & .732 & .798 \\
\hline Adjusted $\mathrm{R}^{2}$ & -.035 & .751 & .807 & -.029 & .717 & .786 \\
\hline $\mathrm{F}$ & .227 & $61.545 * * *$ & $75.684 * * *$ & .347 & $52.108 * * *$ & $66.769 * * *$ \\
\hline$\Delta \mathrm{R} 2$ & & .753 & .055 & & .716 & .066 \\
\hline
\end{tabular}

Note ${ }^{*} p<0.05 ;{ }^{* *} p<0.01 ; * * * p<0.001$

The table 4 shows the outcomes of testing hypothesis in Step 3. Firstly, relationship between trust in management and organizational justice positively and significantly correlated with job satisfaction $(=.407, \mathrm{p}=.00)$, therefore $\mathrm{H} 1$ was supported. This relationship explains that before the inclusion of trust in management into Step 2, organizational justice was significantly correlated with job satisfaction $(\beta=.870$, $\mathrm{p}<0.01$ ). After the inclusion of trust in management into Step 3, the previous significant relationship between trust in management and organizational justice did not change to non-significant (Step 3: $\beta=.538, p<0.01$ ), but the strength of such relationships was decreased. These results send a signal that trust in management acts as a mediating variable in the relationship between such variables.

Secondly, relationship between trust in management and organizational justice positively and significantly correlated with organizational commitment $(=.450, \mathrm{p}<0.000)$, therefore H2 was supported. This relationship explains that before the inclusion of trust in management into Step 2, organizational justice $(\beta=.848, \mathrm{p}<0.001)$ was significantly correlated with organizational commitment. After the inclusion of distributive justice into this Step 3, the previous significant relationship between trust in management and organizational justice did not change to non-significant (step 3: $\beta=.20, p<0.001$ ), but the strength of such relationships was decreased. These results send a message that trust in management acts as a mediating variable in the relationship between such variables. 


\section{Conclusion}

Organizational justice alone does not significantly increase Nurses job satisfaction as well as commitment in the organization. Trust in management mediates the relationship organizational justice and personal outcome. Organizational justice positively affect personal outcome when mediated by high trust in management. Hence, it can be explained that only honorable superior treatment and judgment may not make changes to avoid behavioral problem with coworkers. But it can be achieved through the supervisor/ manager who award nurses on the basis of performance. Only then nurses' emotional attachment towards hospital is high. Further research is needed to test the impact of education level and other demography upon job satisfaction, occupational commitment, occupational stress and others to understand challenges in this profession.

Finding of this research indicate the need for a clinical career ladder for nursing staff. In such ladder, there is grading structure which facilitates career progression by defining different level of clinical and professional practice in Nursing. It has been successfully introduced in other countries such as the U.K (Buchan, 1999). Nurses are fully committed and satisfied if they found such structure to grow themselves with the support of management. Krugman et al.'s (2000) work in the USA found that the use of clinical ladder facilitated nurses' professional development strengthened their organizational commitment and increased their job satisfaction in a study evaluating 10 years of progressive change.

\section{Discussion and Implication}

The findings of this study confirm that trust in management acts as a mediating variable in the relationship between organizational justice and personal outcomes in the hospital. When employees perceive that organizational justice is maintained by the organizations, it increases the feeling of trust in management. As a result, it leads to increased job satisfaction and organizational commitment in the workplace.

Implication of this study can be described into two categories; theoretical contribution and practical contribution. In terms of theoretical contribution, the finding of this study shows that organizational justice to employees and greater trust in management may lead to higher job satisfaction and commitment. This result is consistent with studies by Robinson and Morrison (1995) that trust in managers significantly correlate with OCB to civic virtue dimension. In terms of practical contribution, this study provides practical implications towards nurses and management of hospitals. Management requires change in behavior to develop trusting environment in workplace. Hospital management need paradigm shift towards developing better attitude and professionalism in work behavior. Improved treatment of organizational and developing mutual trust and understanding between management and workers lead to the job satisfaction and commitment.

\section{References}

Adams, JS. (1965). Inequity in Social Exchange. In L. Berkowitz (ed): Advances in Experimental Social Psychology. New York: Academic Press, pp 267-299.

Adhikari, D. R. (2009). Human Resource Management, Kathmandu: Buddha Academic Enterprises Pvt. Ltd.

Adhikari, D. R. and Gautam, D. K. (2010), Labour legislations for improving quality of work life in Nepal, International Journal of Law and Management, 52, 1, 40-53.

Alexander, S., and Ruderman, M. (1987). The role of procedural and distributive justice in organizational behavior. Social Justice Research, 1, 177-198.

Allen, N.J and J.P Meyer (1990). The measurement and antecedent of affective, continuance, and normative commitment to the organization, Journal of Occupational Psychology, Vol. 63

Aryee, S., Budhwar, P. S., \& Chen, Z. X. (2002). Trust as a mediator of the relationship

between organizational justice and work outcomes: Test of a social exchange model. Journal of Organizational Behavior, 23, 267-285.

Bies, R.J and Moag, J.S. (1986). International Justice: communication criteria of fairness. Research on Negotiation in Organizations. (Vol. 1). Greenwich, CT: JAI Press, 43-55. 
Blau, Peter M. (1964). Exchange and Power in Social Life. New York: Wiley

Blomqvist, K., \& Stahle, P. (2000). Building organizational trust. Paper presented at the 16th Annual IMP Conference, Bath, UK

Brown, W.A and Yoshioka, C.F. (2003), "Mission Attachment and Satisfaction in Employee Retention", Nonprofit Management and Leadership, 14 (1): 5-18.

Cummings, L.L., \& Bromiley, P. (1996), The organizational trust inventory (OTI): development and validation, in Kramer, R.M. and Tyler, T.R. (Eds), Trust in Organizations, Sage, Thousand Oaks, CA, pp. 302-330.

Dirks, K. T., \& Ferrin, D. L. (2000). The effects of trust in leadership on employee performance, behaviors, and attitudes: A meta-analysis. Academy of Management Meeting Best Papers Proceedings

Cohen-Charash, Y., \& Spector, P.E. (2001). The role of justice in organizations: A meta analysis. Organizational Behavior and Human Decision Processes, 86, 278-324.

Colquitt, J.A.(2001). On the dimensionality of organizational justice: A construct validation of a measure. Journal of Applied Psychology, 86, 386-400.

Folger, R., \& Konovsky, M.A. (1989). Effects of procedural and distributive justice on reactions to pay raise decision. Academy of Management Journal, 32, 115-130.

Foster, D. P, B. Stine and R. Waterman (1998). Business Analysis Using Regression: A Casebook. Berlin: Springer-Verlag.

Ghimire, B (2012). Organizational Justice and its impact with reference to Nepal. Germany: Lap Publishing

Greenberg, J. (1990). Organizational Justice: Yesterday, Today and tomorrow, Journal of Management, 16, pp. 399-432.

Hair, J. F, R.E Anderson, R.L Tatham and W.C Black (1998). Multivariate Data Analysis. Englewood Cliffs, NJ: Prentice Hall.

Hartman SJ, Yrle AC, Galle Jr. WP (1999). Procedural and distributive justice: examining equity in a university setting, Journal of Business Ethics., 20(4): 337-351.

Herr RM, Bosch JA, van Vianen AEM, Jarczok MN, Thayer JF, Li J, Schmidt B, Fischer JE, Loerbroks A: Organizational Justice is Related to Heart Rate Variability in White-collar Workers, but not in Bluecollar Workers - Findings From a Cross-Sectional Study. Annals of Behavioral Medicine 12/2014; DOI:10.1007/s12160-014-9669-9

Huff, L., \& Kelley, L. (2003). Levels of organizational trust in individualist versus collectivist societies: A seven-nation study. Organization Science, 14, 81-90.

Konovsky, M. (2000). Understanding procedural justice and its impact on business organizations, Journal of Management, 26, pp. 489-511

Lee, C., Law, K., \& Bobko, P. (1999). The importance of justice perceptions on pay effectiveness: a two year study of a skill-based pay plan. Journal of Management, 25, 851-874.

Lind, E. A., \& Tyler, T. R. (1988). The social psychology of procedural justice. New York: Plenum Press.

Luthans, Freed., (1996). Organizational Behavior. New York: McGraw Hill Book Companion.

McFarlin, D. B., \& Sweeney, P. D. (1992). Distributive and procedural justice as predictors of satisfaction with personal and organizational outcomes. Academy of Management Journal, 35,(3), 626-637.

Mikula, G., Petrik, B., Tanzer, N. (1990). What people regard as unjust: types and structures of everyday experiences of injustice. Euro Journal of Social Psychology. 20(2): 49-133.

Moorman, R. H. (1991). Relationship between organizational justice and organizational citizenship behaviors: Do fairness perceptions influence employee citizenship? Journal of Applied Psychology, 76(6), 845-855.

Mowday, R. T, R.M Steers and L.W Porter (1979). The measurement of organizational commitment, Journal Vocational Behavior, 14, 224-247.

Nunally, J. C and I.H Bernstein (1994). Psychometric Theory. New York: McGraw-Hill.

Niehoff, B.P., \& Moorman, R.H. (1993). Justice as mediator of the relationship between methods of monitoring and organizational citizenship behavior, Academy of Management Journal, 369(3): pp. 527- 556.

Pandey, D. L. (2008), Expected training benefit and organizational commitment: a study of Nepalese service sector, unpublished M. Phil. Thesis submitted to Faculty of Management, Tribhuvan Universality, Nepal.

Ponnu CH, Tennakoon G (2009). The association between ethical leadership and employee outcomes: The 
Malaysian Case', Electronic. Journal of Business Ethics. Org. Stud., 14(1): 21-31.

Rhodes, Susan R. and Steers, R. M. (1981). Conventional vs. Worker Owned Organizations. Human Relations 43 (12): 1013-1035.

Robinson, L. L., \& Morrison, E. W. (1995). Organizational citizenship behavior: A psychological contract perspective, Journal of Organizational Behavior, 15, pp. 289-298

Sekaran, Uma. (2000). Research Methods for Business: A Skill Building Approach. John Willey \& Sons, Inc

Sheppard B, Lewicki R and Minton J (1992), Organizational Justice: The Search for Fairness in the Workplace, Lexington.

Shrestha, Y. K. (2006), Human resource management and organizational performance: an evidence from Nepalese Banking Industry, unpublished thesis, M.Phil. in Management, Tribhuvan University, Kathmandu.

Vecchio, P. R, G. Hearn and G Southey (1992). Organizational Behavior. Sydney: Harcourt.

Warr, P. B, J Cook and T.D Wall (1979). Scales for the measurement of some work attitudes and Aspects of psychological well-being, Journal of Occupational Psychology, Vol. 52, pp. 129-148.

Whitener E. M. (1997). The impact of human resource activities on employee trust. Human Resource Management Review 7:389-404.

Wong, C. S., and Kung, H. L. (1999). An exploratory investigation on commitment to specific constituencies in Taiwan. Chinese Journal of Psychology, Vol. 40, No. 1, 1-13.

Rousseau, D., Sitkin, S., Burt, R., \& Camerer, C. (1998). Not so different after all: A cross-discipline view of trust. Academy of Management Review, 23, 393-404.

Spector, P.E.(1997) Job satisfaction; Application, Assessment, Causes and Consequences. SAGE Publication, London.

Sun Y.F., Yan, L.H,Kong.,(2001) The psychological reasons and counter measures for nurses leaving their positions. Chinese Journal of Nursing 36(2), 92-94.

Sweeney, P. D., and McFarlin, D. B. (1993). Workers' evaluations of the "ends" and the "means": An examination of four models of distributive and procedural justice. Organizational Behavior and Human Decision Processes, 55, 23-40.

Yousef, D. A. (1998). Satisfaction with job security as a predictor of organizational commitment and job performance in a multicultural environment. International Journal of Manpower, 19, 184-194. 